\section{JCL}

Journal of the College of Languages

Open Free Access, Peer Reviewed Research Journal

Est.1994

\section{http://jcolang.uobaghdad.edu.iq}

\title{
Pragmatic Analysis of the Translation of English Culture- Specific Proverbs into Arabic
}

\author{
Asst. Professor Abdali H. Al-Saidi (Ph.D.)
}

E-mail : brunosaidi8@yahoo.com

Thiqar University, College of Arts, English Department, Thiqr, Iraq.

( Received on 11/9/2020 - Accepted on 20/10/2020 - Published on 2/1/2021 )

DOI: https://doi.org/10.36586/jcl.2.2021.0.43.0030

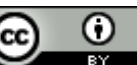

This work is licensed under a Creative Commons Attribution 4.0 International License.

\begin{abstract}
Translating culture-specific proverbs (CSPs) is a challenging task since they often occur in a peculiar context. Further, CSPs are intended to imply meanings that extend far beyond the literal meaning of such a kind of proverbs. As far as English and Arabic are concerned, translators often encounter problems in translating CSPs due to cultural differences between the source language(SL) and the target language (TL) as well as what seems to be the lack of equivalence for some CSPs.

In view of this, the present study aims at investigating the translation of CSPs in three English-Arabic dictionaries of proverbs, namely Dictionary of Common English Proverbs Translated and Explained (2004), One thousand and One English Proverbs Translated into Arabic (2008) and Dictionary of Wise Sayings and Proverbs (2009). Data of CSPs, in the aforementioned dictionaries, are analyzed as a case study. Specifically, the study attempts to examine whether CSPs are well translated and whether the translation strategies utilized have reflected
\end{abstract}


the ST intended meaning (IM) and the embedded cultural implications as well. Out of the total data on CSPs, only ten examples are selected as representative samples for analysis. For the purpose of carrying out a meaningful analysis of the translation of CSPs, an eclectic model is adapted. It consists of Baker's (2011) cultural substitution strategy (CSS) in combination with Venuti's (2008) domestication strategy (DS) and Nida's (1964/1975) Functional (closest natural) equivalent as well. This proposed eclectic model was considered as the main theoretical framework of the study.

Findings of the study revealed that the selected data have often shown low levels of adequacy in terms of expressing the meanings and pragmatic functions of the ST in the TT. Specifically, the selected translators provide inadequate translations of the cultural implications of the ST in the TT. In addition, this study concludes that translators can successfully render the intended meanings and the cultural elements of CSPs had they been not only bilingual but also bicultural since Arabic, particularly the Qur'an, Hadith, and the Arabic literature, is rich with CSPs that cover issues corresponding to those found in English proverbs. It is worth noting that even if the TL equivalent exists, it would not necessarily accomplish complete equivalence since the ways of expressing meaning and the usage of proverbs differ among languages.

Key words: CSPs, culture, translation, translation strategy

\subsection{Introduction}

In every language, proverbs are used to express particular messages. However, when proverbs are transferred from one language to another, certain translation problems emerge due to particular cultural and linguistic implications proverbs connote. In this section, key concepts namely proverbs, CSPs, translation, translation strategy, and culture are highlighted. In addition, the problem of the study along with the research questions will be stated clearly. 


\subsection{Translation and Culture: Definitions and Interrelatedness}

Many recent translation studies have been largely concerned with the definitions of translation and the interrelatedness it has to culture (2010; Baker, 2011; Abbasi et al, 2012; Ghazala, 2014; House, 2015, Assaqaf, 2019; Alfaleh, 2020). In detail, translation is roughly defined as a crosscultural activity of transferring meaning from one language to another. Undoubtedly, such a task requires a translator to have a cross-cultural competence and dexterity to deal with nuances of cultural implications of the text s/he is working on. In addition, Abbasi et al. (2012) point out that translation is

not just a literal recasting of a work from one language to another, but also as an adaptation of one culture' $s$ values and biases into another $\cdots$ To translate means to circulate, and this is what our world really needs: the freedom to find the right ways to express itself, to understand and to be understood out there, by the other (p. 86).

As for House (2009), translation is not only "a linguistic act; it is also a cultural one" (p.11), and translation is viewed as the replacement of a text in the SL by a semantically and pragmatically equivalent text in the TL (House, 2015, p. 63). However, translation of CSPs is of a big challenge since to translate them is to interpret the meaning in relation to comparable items in the TT culture which means that translation problem lies in that proverbs contain not only linguistic but also culture features (Al-shammari, 2015, p. 47)

In the same vein, culture plays such a super important role in shaping, comprehending and translating language to the extent that Casagrand (1954) states that "one does not translate language, one translates culture" (p.338, italics mine). Larson (1984) defines culture as a complex set of "beliefs, attitudes, values and rules which a group of people share" (p. 431). In more detail, culture comprises a system of interrelated beliefs, values strategies and cognitive environment which all 
participate in guiding one's behaviour. In a much similar way, culture is what influences the behaviour of society members and their interpretations of the meaning related to others' behaviour (al-Saidi, 2016b; see Katan, 2004; Spencer-Oatey, 2008 ). Besides, Nida (1999, p.2-7) states that language and culture are closely interrelated and similar interdependent systems, i.e., they influence each other. Thus, a translator should carefully consider both the linguistic and the cultural differences when translating a cultural text into another listener or audience; since language and culture co-exist, and the former does not exist apart from the latter (Sapir 1970:2017; see Daghoughi, , 2016, p.171).

In this study, culture is very much associated with the shared principles people use to co-ordinate and communicate their activities and it is closely linked to "the knowledge, activities and artifacts associated with a given language community and which provides added meaning to the basic linguistic, referential meaning of words (Palumbo, 2009, p.31 cited in al-Saidi, 2016, p.29) In other words, socio-cultural knowledge, in the sense stated above, determines the way people interpret, use and perceive the messages implied in the intercultural and cross-cultural linguistic codes of CSPs.

\subsection{Proverbs: Definitions and Stylistic Features}

Proverbs are undoubtedly the product of certain experience and history of a given nation. The major traditional function of proverbs is didactic since they are taught to be applied on similar contexts. Specifically, proverbs are defined as short sayings that can convey themes "exquisitely crafted sayings in which minimal words are arranged for maximal effect. They are shaped so as to be memorable and persuasive, to encourage virtue and discourage vice, but they do so indirectly or even covertly (Miller-Naude, 2010, p. 309; Mieder, 2008, p.11). Despite the fact that proverbs are short sayings that can convey themes and messages of a whole nation in such an expressive manner to communicate cultural beliefs and values, proverbs pose many translation problems since they are strongly associated with social events and stories that are deep-rooted in culture (Al-Azzam, 2017, p.56; Samover et al, 2009, p.29). 
Furthermore, proverbs are viewed in terms of their stylistic features, which are stated by Arora (1995, p. 7), (see Abu Timen, 2015, p.14021 and Alfaleh, 2020) as follows:

Alliteration: (Practice makes perfect)

Parallelism: (Nothing ventured, nothing gained)

Rhyme: (No pain, No gain)

Ellipsis: (Once bitten, twice shy)

Arora (1995, p. 7) also proposes some internal features of proverbs which are as follow:

Exaggeration: (All is fair in love and war)

Paradox: (Easy come, Easy go)

Personification: (Hunger is the best cook)

It is of much importance to note that the above stylistic features are what provide proverbs with richness. These stylistic features include two kinds of markers, namely structural markers such as parallelism and poetic markers such as rhyme or the use of figurative language such as metaphor. The stylistic property of a proverb is as important as its meaning, especially that its poetic quality is a cultural product which should be faithfully transferred in translation (Issa, 2017, p. 65; Zahrawi, 2018, p.4).).

Most importantly, CSPs are special, fixed, unchanged phrases which have special, fixed, unchanged meaning since their function is to transfer unique SL cultural meanings. They are culture-specific utterances whose meanings are often difficult to grasp for not only nonnative speakers but also for the native speakers of the SL. (Ghazala, 1995, p.142; see also al-Shammari, 2015; Shehab, and Daragmeh, 2015). In other words, CSPs are such elements of a given literary text that are closely associated with the SL culture and alien to the TL audience ( Zahrawi, 2018; Nord, 1997). According to Ghazala (2014) proverbs in general, and CSPs in particular, are not meant to be taken literally and 
directly by simply identifying their word-for-word equivalence. This signifies the importance of looking at proverbs beyond their denotative meaning since literal translation most likely leads to incomprehensible TT or what seems to be linguistically equivalent may very often appear as a non-equivalent (Al-shammari, 2015; Alfaleh, 2020).

With all this in mind, the problem to be stated in this study is that since translation, as Landers (2001) points out, is not intended to render what the ST producer says or writes but what s/he meant, this study is mainly concerned with CSP non-literal meanings and implicit connotations. Accordingly, CSPs are difficult to translate adequately since they convey meanings that are largely embedded in cultural and ideological structure. Besides, CSPs, then, are "multi-faceted linguistic expressions in which form and meaning intersect in complex ways and they are thus one of the most difficult kinds of texts to translate" (Naude, 2010, p.309). In this case, a translator of CSPs is required to be highly attentive to not only the linguistic differences between the source and target languages but also to the gaps which resulted from the stylistic, epistemological and cultural disparities of both cultures. "Such gaps exist when there is simply no equivalence for a word in the TT, when the connotation of a word is completely different in the TL and when values and beliefs do not overlap in both cultures" (Zahrawi, 2018, p.5).

It is worth noting that nothing is untranslatable since anything that can be said in one language can be conveyed in another (al-Saidi, 2016). The peculiar character CSPs merit, in terms of their linguistic style and figurative language, requires a translator to have an active hand in the intercultural translational process since translation cannot travel to a new surrounding without adapting to a new environment (Naude, 2010; Zahrawi, 2018). Based on the problem stated above, the study addresses the following research questions:

1. In the selected dictionaries, have the translators succeeded in grasping the ST intended meanings and functions and rendered them adequately in the TT?

2. What translation strategies have the selected translators employed to render CSPs from the SL into the TL? 
3. What alternative translation strategies has this study recommended to translate the CSPs more adequately?

The significance of this study stems from the fact that many research papers have examined the difficulties translators encounter while translating proverbs in general and CSPs in particular. However, systematic and practical studies on investigating and assessing the translation of CSPs in English-Arabic dictionaries seem to be quite limited. The present study was conducted to fill the gap in the literature on translation studies. Specifically, this study addresses CSPs in terms of their social, cultural and linguistic implications that seem not to be well communicated in the TL.

\subsection{Literature Review}

This subsection is concerned with providing a brief critical review of the very recent related $\mathrm{s}$ studies that have previously examined the translation problems associated with proverbs, especially the translation of CSPs. In addition, the related studies are viewed chronologically in terms of their focus, significance and findings.

In a paper on the significance of context in translation in general and the translation of proverbs, in particular, Ekrema and Daragmeh (2014) conducted a context-based approach to the translation of proverbs. Specifically, the study is basically concerned with "proverb's contextual meaning, linguistic form, speakers, and addressees and thus presents target readers with its context-based equivalence(s) and not with its most circulated version(s)" (p.51). The study concluded that most Arabic proverbial expressions are often used ironically to imply the opposite of what is being said because translators often do not seriously consider a proverb-related context. 
On a different note, Abo Al-Timen (2015) investigated the translation methods employed to render proverbs with the minimum loss of the proverb connotative meaning. In order to do so, the researcher analysed 49 proverbs in terms of literal, literary and substitution strategies. She concluded that translating proverbs requires a great deal of attention to the cultural, religious and historical background relevant to the proverbs under analysis.

In the same vein Dweik and Thalji (2016) examined the strategies employed in translating proverbs from English into Arabic. Specifically, they have explored the translation strategies used by Jordanian novice translators when tackling the rendition of proverbs from English into Arabic. For this end, the researchers have selected 20 novice translators as their sample for the data test. The test consists of ten English proverbs based on Speake's categorization. The findings of the study revealed that the translation strategies employed are ranging from cultural equivalence and literal strategy to paraphrasing and glossing.

On a different level, Bahumaid (2017) investigated the difficulties and implications of culture-bound terms (CBTs) in Arabic-English translation. Specifically, the study further explores the trainee translators' awareness of the translation strategies they utilize in their renditions. For this purpose, a text of fifteen contextualized Arabic culture-bound terms is designed as a research instrument. Results of the study revealed that the informants have shown low performance in translating CBTs due to the lack of awareness of cultural background and inadequate proficiency in handling idiomatic CBTs.

Similarly, Zahrawi (2018) explored the translation of culture-specific items (CSIs), such as proverbs in terms of evaluating the strategies used in translating two Arabic plays: Sa' dallah Wannous' s The Glass Café (1978/2004) and Mamdouh 'Udwan' s Reflections of a Garbage Collector (1987/2006). The findings of the study reveal the translation strategies used in these two plays are recognized and rationalized in terms of giving a domesticated or a foreignized effect. In 
both translated plays, the TTs have varying degrees of foreignization and domestication.

In a relevant study, Assaqaf (2019) investigated the techniques used for interpreting English proverbs into Arabic. Data of the study were collected from two popular dictionaries, namely the Lamps of Experience: a Collection of English Proverbs by Ba' alabaki (1980) and a Dictionary of Proverbs: English-Arabic by Kilani and Ashour (1991). Data analysis revealed that a variety of techniques can be employed in dealing with the translation of proverbs. Translators can prioritize the techniques according to the workability they offer in adequately expressing the ST intention in the TT.

Quite related to the present study, Al-Faleh (2020) has conducted a translation quality assessment to the translation of proverbs from English into Arabic selecting a published dictionary, namely One Thousand and One English Proverbs Translated into Arabic, as a case study. The researcher has utilized Na Pham's error analysis model as a framework for the data analysis to detect the most common errors committed in the translation under analysis. The researcher has concluded that certain types of errors occur more often than others. In addition, most of the errors committed when translating proverbs are resulted from employing literal translation.

In the light of the related studies reviewed, it seems obvious that they have very rarely touched upon the retention of CSPs. In addition, those studies have tackled the problems and difficulties attributed to mistranslation of proverbs, but most of them seem somehow simplistic and incomprehensive. Furthermore, two studies only have examined the translation of proverbs in English-Arabic dictionaries; however both of them appear to lack in-depth systematic analysis as compared to the present study.

\subsection{Theoretical Framework}


For the purpose of conducting a meaningful analysis of the translation problems encountered while rendering CSPs from English to Arabic, an eclectic model is adapted. Three translation strategies, namely Baker's (2011) cultural substitution strategy (CSS), Venuti's (2008) domestication strategy (DS) and Nida's (1993) functional, (closest natural) equivalent, are utilized. This proposed eclectic pragmatic model was considered well-balanced as the main theoretical framework of the study since this model is hoped to largely minimize the loss expected in translating CSPs from English into Arabic. Bearing in mind that translation, as a cross-cultural communicative activity, should be faithful to the content of original in the first place focusing basically on what the ST producer intends rather than what s/he says. Translation in this sense is a "re-coding" or a change of surface structure in representation of the deep structure underlying it $(\mathrm{Wu}, 2008, \mathrm{p} .123)$. On this basis, the proposed model is hoped to be a functional middle-course strategy to best maintain the embedded meanings and functions of the original CSPs in the TT.

Baker believes that culture poses a great deal of difficulties and problems to translators when they work on texts, proverbs for instance, that are loaded with cultural implications. Thus, she stresses that the role of a translator is not only translating language but also translating culture (Baker, 1992; Thalji, 2015). For this purpose, she proposed many translation strategies particularly CSS, which is the major concern of this study. Specifically, Baker (2011) stresses that

This [cultural substitution] strategy involves replacing a culture-specific item or expression with a target-language item which does not have the same propositional meaning but is likely to have a similar impact on the target reader. The main advantage of using this strategy is that it gives the reader a concept with which s/he can identify, something familiar and appealing (p.31).

For instance, a CSP like 'as wise as an owl' where the word 'owl' stands for wisdom in English and, in this case, the said word indicates a positive cultural connotation while the case is totally the opposite in Arabic where 'owl' indicates bad omen. Thus, there is a gap between the SL and the TL 
regarding the cultural sign embedded in the proverb. In this case, CSS is best fitting to translate the proverb in question into "حكيٌ كلقمان"(lit. as wise as Luqmān) by replacing 'owl' with 'لقمان' (Luqmān is one prophets mentioned in the Qur'ān as a symbol for wisdom) )( see Abo al-Timen, 2015, p. 14024-25). In this respect, Nord (1991, p.7) emphasizes that "both the source and target texts are determined by the communicative situation in which they serve to convey a message". However, CSS should be used cautiously and carefully when dealing with texts whose historical background is very important where "translators are motivated to make some additional appropriate changes in the text they are translating in order to achieve the cultural appropriateness" (Benard, 2018, p.73).

Similarly, Venuti's (1995/2008) DS to translation makes the SL text more readable and best understandable to the TL readers since this translation strategy makes the SL identical to the TL culture. According to Venuti (ibid.), DS is an "ethnocentric reduction of the foreign text to the target cultural values, bringing the author back home"(p.20). As far as translation of CSPS from English into Arabic is concerned, DS can easily bridge the cultural gaps between the ST and the TT norms where CSS is also included in the process of using the DS. It is better to skillfully bring the ST norms back home through substituting them by some TT domestic norms instead of rendering them literally (Al-Saidi, 2014).

Besides, domestication "makes translation more transparent and fluent for target readers through linguistic and cultural modification" (Herrag, 2012, p.22). Further, resorting to DS in translating CSPs helps to minimize the foreignness of TT but this translation strategy should not be utilized limitlessly. Additionally, al-Dammad (2004) reports that native Arab translators often use domestication most of the time when they translate into Arabic, especially when dealing with culture-loaded texts. For instance, a highly CSP such as "to eat someone out of house and home" (Shakespeare, Henry IV, 2:1), which means eating so much as to deplete someone's resources, can be best domesticated in the TL via 
using a functional equivalence such as " أكل الجمل بما حمل"(Al-Shammari, 2015).

Nida (1993), proposed the functional (dynamic) equivalence as the best strategy in transferring culture-specific expressions. Functional strategy (FS) can be defined as "reproducing in the receptor language the closest natural equivalent of the source language message, first in terms of meaning and secondly in terms of style." (Nida and Taber, 1969, p.12). In Nida's definition, three basic translation terms are skillfully utilized, i.e.closest, natural and equivalent, which require more clarification. It is worth noting that "equivalent", in Nida's definition "does not refer to the meaning of total identity but rather to proximity and similarity that are implied in the use of closest" (Al-Saidi, 2016b, p.53). The term natural requires that the translation should be readable in terms of language form, and understandable, in terms of content, to the target receptors (Zhang, 2010). As far as the term closest is concerned, it is highly linked to the degrees of proximity between the ST and the TT (AlSaidi, 2016b; see Farahani \& Ghasemi, 2012, Al-Sahmmari, 2015).

Nida's functional strategy (closest natural equivalent) is utilized in case:

1. literal and formal translation leads to misunderstanding of the $\mathrm{S}$ designative meaning,

2. formal translation makes no sense,

3. a close, formal translation is likely to distort the associative meanings of the original in terms of stylistic value.

In all these cases, proper adjustments are required to reflect the ST associative values in the TT. In this regard, Nida (2001) asserts that FE is best viewed in terms of 'the range of adequacy' in translation since this kind of equivalence indicate that complete or total equivalence does not exist, but different translations show varying degrees of equivalence( AlSaidi, 2016b, p.51-53). For example, a proverb such as "one must take the rough with the smooth" means that one does not have to expect one's road through life to be always easy. Thus, one should accept bad times philosophically" (Ridout and Witting, p.154). This CSP can be well communicated by a highly closest natural equivalent like the following: 


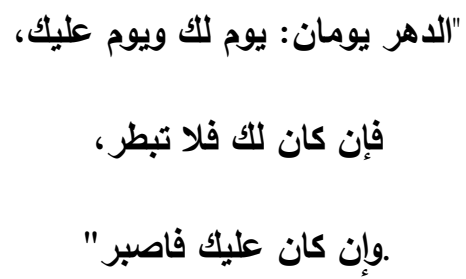

( Nahjulbalagha)

In conclusion, it is important to identify the fact that the model of analysis in this study is basically pragmatic. Specifically, it is mainly concerned with two major concepts, i.e. pragmatic meaning and function, which have to be identified below:

Pragmatic meaning, the intended meaning (IM), refers to the study of meaning from the language user's intention since $\mathrm{s} / \mathrm{he}$ often means more than what is literally said (Searle, 1969; Thomas, 1983; Baker, 2011). In this study, the IM is more concerned with the implicit meaning the CSPs tend to express.

Pragmatic function refers to the force or effect a given speech act entails in addition to the meaning it expresses and it refers to the embedded associative connotations of a word or an expression that carries implicit meanings (Searle, 1969, 1979; Baker, 2011; see Al-Saidi, 2016b).

\subsection{Methodology}

\subsection{Approach and Data of the Study}

This study is qualitative in nature for it is basically concerned with text analysis. It is a descriptive study according to which translations are not assessed in terms of right-wrong criteria but rather in terms of adequate/inadequate quality. It adopts a corpus-based analysis approach to identify the translation problems of CSPs from English into Arabic. Out of the total data of the study that comprise (50) examples, only 10 typical illustrative CSPs are extracted from a corpus consisting of the original CSPs and their translated versions in Arabic. 


\subsection{Data collection and Analysis Procedures}

The procedure for getting the required data is composed of four stages which can be summarized as follows;

(1) Reading the original text of the selected English-Arabic dictionaries, namely Common English Proverbs Translated and Explained (2004) by Attia, One thousand and One English Proverbs Translated into Arabic (2008) by Jabak and Dictionary of Wise Sayings and Proverbs (2009)by Nasif and extracting the proverbs with culture-specific items;

(2) Finding their equivalents in the Arabic translated versions in the same dictionaries;

(3) Identifying the translation strategies applied based on Baker (2011), Venuti (2008) and Nida (1984/1993) as the model for analysis in this study, and

(4) Examining whether the intended communicative meaning and function of CSPs have been preserved in the translated versions or not.

\subsection{Limitation of the Study}

The data of the study consist of (50) English CSPs along with their Arabic translation. It is limited to CSPs only where (10) sample examples are selected for data analysis. The analysis deals with CSPs in terms of whether the meanings and functions they convey have been well communicated in the Arabic translations or not. Further, since this study is basically pragmatic, the ST intention is prioritized to linguistic structure and style.

\section{Rationale for Data selection}

In this study, the data are selected for the following reasons:

1- CSPs constitute a challenging area in translation studies;

2- Studies on CSPs in English-Arabic dictionaries are very limited; 
3- The Arabic versions of the ST are assumed to show translators' insufficient socio-cultural and pragmatic knowledge of the ST and even the TT, sometimes.

\subsection{Data Analysis}

The data of this study are analyzed as follows:

The first step is to determine the ST intentionality and function via providing its linguistic and socio-cultural background. For this purpose, two popular English dictionaries of proverbs are consulted, namely, English Proverbs Explained (1983) by Ridout \& Witing, Oxford Dictionary of Proverbs (2008) by Speake. Second, the TT examples are examined through comparing and contrasting the meaning and connotations CSPs convey with the ST intended meaning. Third, the TTs are further analyzed according to the eclectic pragmatic model proposed in (3.0) above. The said model is adapted for it seems more applicable and workable to the analysis of the translations of CSPs in the data selected. In other words, the model utilized can provide the translator with the freedom required to opt for more communicative rendering of CSPs (see Al-Saidi, 2016b). It is worth noting that the proposed translations of CSPs are taken from the Qur'an, Hadith, and Arabic literature in general, which prove to be a rich source for identical cultural equivalents to the English CSPs.

\section{Results and Discussions}

This chapter presents the analysis and assessment of the translations of CSPs in three English-Arabic dictionaries, referred to above. This section provides an overall account of the data analysis and the assessment of the translations of the meanings and functions conveyed by the identified CSPs in the above-mentioned dictionaries and other sources. In terms of data analysis, CSPs were analysed contextually and textually whereby contextual analysis provides adequate knowledge on every single proverb 
in terms of the relevant socio-cultural and situational information. This is to determine the ST intended meaning(s) and function(s).

1. "Sweet are the uses of adversity " (Ridout \&Witting, 1983, p.153)

\begin{tabular}{|l|l|}
\hline & " Sweet are the uses of adversity" \\
\hline & "misfortunes can sometimes be a blessing in disguise" (p.153) \\
\hline & " لذيذة هي استعمالات المحنة/المحن تكثف النفوس " (Jabak, 2008, p.61) \\
\hline
\end{tabular}

In example (1), the CSP refers to the fact that "misfortunes can sometimes be a blessing in disguise. In Shakespeare's As You Like It, the exiled duke in the forest of Arden finds he has much to be thankful for.

"Sweet are the uses of adversity,

Which, like the toad, ugly and venomous,

Wears yet precious jewel in his head...."

(Ridout and Witting, 1983, p.153, italics mine).

Thus, the ST intended meaning is basically concerned with the fact that misfortunes sometimes run counter to one's expectation since they, at times, come up with positive consequences.

لذيذة " In the example above, the ST is firstly translated literally into " in that the word 'uses' is rendered into " استعمالات استعمالات المحنة " (lit. uses) where the meanings intended, within the overall socio-cultural context, is "فو ائد، منافع" (lit. profits, advantages). Similarly, "sweet" is transferred into " لذيذة " لذغيمة، مباركة " (lit. delicious) where it means " (lit.

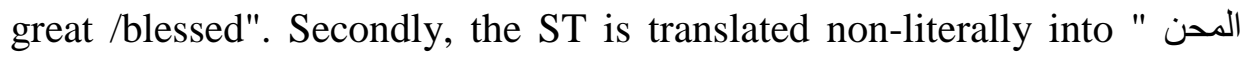
" "نكثف النفوس "lit. misfortunes uncover people's real selves", which has nothing to do with the ST intention, stated above. Specifically, the focus in this translation is on viewing adversity as a test to discover people's real selves, which is not intended in the ST. 
The translator seems to be inattentive to the ST intended meaning and he may lack the required knowledge about the cultural dynamic equivalence available in the TL. Consequently, the TT versions are inaccurate and unfamiliar to the Arab readership since they neither reflect the ST meaning nor do they convey its function. In the light of Nida's (1993) FE and Venut's (2008) DS, the ST can be best translated into a

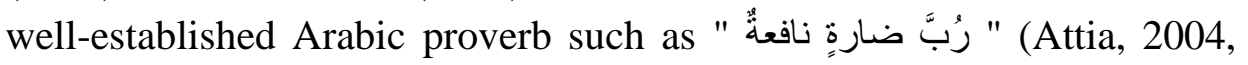

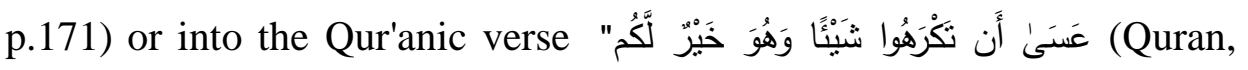
2:216) "and it may be that you dislike a thing while it is good for you" ( Shaker, 2008), where the ST is functionally communicated and domesticated in the TT.

2. " A cat may look at the king " (Ridout \&Witting, 1983, p.37)

\begin{tabular}{|l|l|}
\hline & " A cat may look at the king " \\
\hline & "no one is beyond looking at or being criticized " (p.37) \\
\hline & " تستطيع القطة أن تنظر للملك " (Attia, 2004, p.23) \\
\hline
\end{tabular}

The CSP in example (2) means that "if a cat may look at a king, I have as much right to take an interest in what you are doing. Are you so important that I cannot even look at you?" (Ridout \&Witting, 1983, p.37). In other words, there is no such an important person who one cannot look at and criticize his/her behavior since even a cat can look at a king (see Attia, 2004). In the example above, the CSP is transferred literally to " تسنطيع القطة أنْ تنظر للملك ", which is an inaccurate rendition since it does not indicate the ST intended meaning at all. In this case, it seems that the translators have not consulted the TL to find the required closest natural equivalent (Nida, 1993), but he seems to have depended on his own interpretation of the ST. This literal translation may lead to having a vague and incomprehensible TT version, which may look meaninglessly alien to the target reader (see al-Faleh, 2020).

Based on Venuti's (2008) DS, the CSP above can be rendered dynamically into the following commonly used Arabic religious proverb: " Nasif, 2009, p.160). This Arabic counterpart of the ST 
conveys not only the meaning of the ST but also its function. It is worth noting that Nida (1984) asserts that a translator should resort to FE strategy in translating culturally-bound expressions when literal translation makes no sense, or it leads to misunderstanding of the ST designative meaning and if literal and formal translation is likely to distort the associative meaning of the original.

3. " Give the devil his due " (Ridout \&Witting, 1983, p.74)

\begin{tabular}{|c|}
\hline " Give the devil his due " \\
\hline $\begin{array}{l}\text { "even the very bad sometimes do a good deed, so we should } \\
\text { recognize the good points of others, even though they are not } \\
\text { friends of ours" (p.74) }\end{array}$ \\
\hline 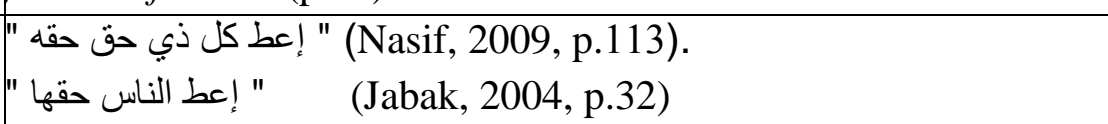 \\
\hline
\end{tabular}

The CSP in example (3) means that we should give our foe proper credit even $\mathrm{s} /$ he is like the devil (Spears, 2005, p. 253). In other words, no one is absolutely evil since good and evil are relative for even the evilest people can sometimes do good deeds. Thus, the cultural aspect in the above CSP is the word 'evil' since it is the focus point which provides force to the ST intended meaning. In the translation, the ST is rendered to "إعط كل ذي حق حقه" (1it. give everyone his due) and " إعط الناس حقها (1it. Give all people their due" by Nasif and Jabak, respectively. The key word evil is omitted in both translations and this makes the translation more general and void of the ST function and flavour. Both translators seem to be unaware of the significance the word 'evil' has in the ST which, on the one hand, intensifies the meaning of justice to the extent that even the devil should be well-treated when it comes to rights. On the other hand, the word evil emphasizes the 
fact that even the evil persons can do good things (see AlFaleh, 2020, p. 36).

In accordance with the pragmatic model adapted, the ST can be well communicated in the TT via providing the closest natural equivalent, i. e. " إعطِ كلَّ ذي حقٍ حقه حتى لو كان " (Attia, 2004, p. 64), which conveys both the ST meaning and function since maintaining the word "شيطان " (1it. devil) in the translation reflects the ST cultural connotation which implies the meaning of evil.

4. "One man's meat is another man's poison "(Ridout \&Witting, 1983, p.134).

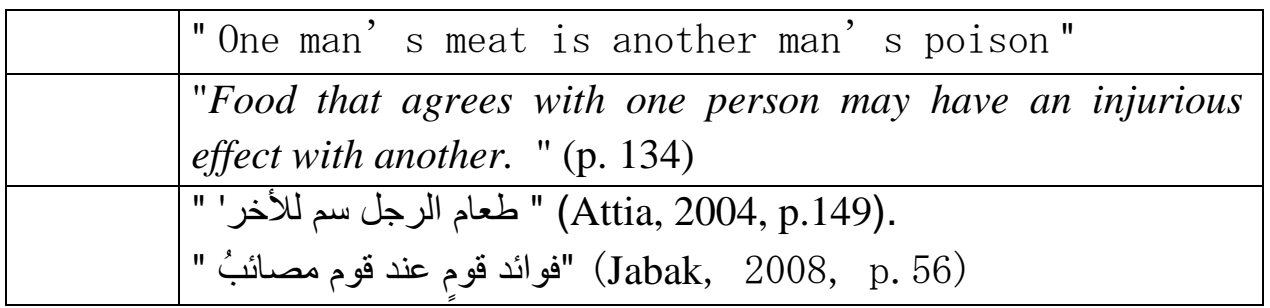

In a wider sense, the meaning of the above CSP is that" one person may like what others hate" (Ridout \&Witting, 1967, p. 134). More specifically, "something that one person likes may be distasteful to someone else" (Spears, 2005, p. 473). In light of this, the ST conveys more than one cultural connotation such as the fact that diverse likings of people are bliss since this is the very nature of existence. Consequently, people are required to highly consider and respect the way they are different in looking at and perceiving things around them.

In line with this, Attia's translation of the ST into " is too literal to the extent that it seems 
to fail in rendering the intended meaning, highlighted above, and the ST cultural connotations. Similarly, Jabak has rendered the CSP into (an ) inaccurate, though looks functional, counterpart since he does not quote AlMutanabi's famous line" مصائبُ قومٍ عند قوم فوائد correctly. Besides, the ST intention is different from that of the translation proposed since the socio-cultural and situational context relevant to Al-Mutanabi's line of poetry is more about loss and gain (Al-Faleh, 2020), whereas the CSP is mainly concerned with the diverse liking and disliking of people. It is obvious that there is no identical formal equivalent of the ST in the TL. However, "stylistic and figurative language are cultural products that should not be eliminated in the TT" ( Zahrawi, 2018, p.6). Thus, ST can be better transferred to a frequently used Arabic proverb "لولا إختلاف الأذواق لبارت السلع", which seems to well communicate the meaning and function of the original.

5. "He that lies down with dogs must rise up with fleas. "(Spears, 2005, p. 325).

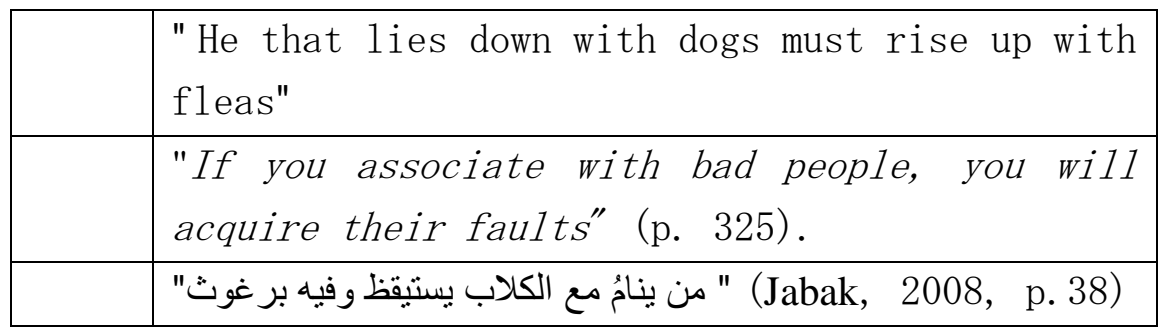

In example (5) the ST meaning is that your real social value is measured according to the company you associate yourself with, i.e. the people you befriend. Thus, the 
message this CSP conveys is that one has to be so careful in choosing the people one takes as his friends, as clearly stated by a similar proverb like " men are known by the company they keep" (Ridout \&Witting, 1967, p. 118).

With all this in mind, Jabak has rendered the above proverb into" من ينامُ مع الكلاب بستيقظ وفيه برغوث ". This rendition is too literal where the ST intention is not only mistranslated but it is also distorted. It is worth noting that proverbs in general and CSPs in particular, are not meant to be taken literally and directly by simply identifying their word-for-word equivalence (Ghazala, 2014, p.144). However, the bad connotations associated with 'dogs' and 'fleas', which indicate the consequences of having bad company, can be maintained in the TT via utilizing CSS along with DS. Accordingly, the ST can be well communicated in the TT as in the following Arabic counterpart:

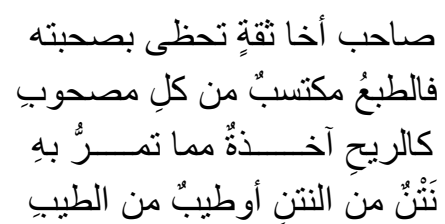

Thus, the translator is likely to have never done his best in looking for the right equivalent of the ST in the TL. Arabic and English have a lot in common regarding concepts such as friendship, love, hatred, among other things. Thus, Arabic is rich with pragmatic functional equivalents to the CSP above. For instance, counterparts

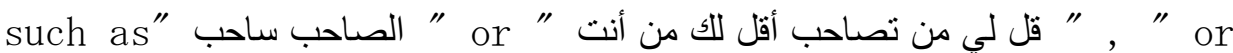
" are sociopragmatically identical to the ST intention and function ( see Attia, 2004, p. 127; see Al-Faleh, 2020). 
6. "Gather ye rosebuds while ye may" ( Ridout \& Witting, 1983, p.72).

\begin{tabular}{|c|}
\hline " Gather ye rosebuds while ye may". \\
\hline $\begin{array}{l}\text { "take advantage of your opportunity before it } \\
\text { is too late" (p. } 72) \text {. }\end{array}$ \\
\hline $\begin{array}{l}\text { "اقطف الورد بينما نستطيع/ اغتتم الريح الطيبة" (Attia, 2004, } \\
\text { p. 63) (Jabak, 2008, p.) }\end{array}$ \\
\hline
\end{tabular}

The CSP, in example (6), means that you should" take advantage of your opportunities before it is too late $\cdots$ this proverb comes from Robert Herrick's 17th-century poem " To the Virgins, to make Much of Time". Here are the first and the last of the four stanzas:

Gather ye rosebuds while ye may,

old Times is still a-flying:

And the same flower that smiles today

Tomorrow will be dying"

(Ridout \& Witting, 1983, p. 72)

In view of this, the ST intended meaning is that we have to fully enjoy our present moment since we never know what will happen next or what tomorrow will bring. In other words, one has to enjoy one's good times by seizing the opportunity best since it strikes but once.

In the cited translations, the ST is rendered into " إقطف الورد بينما تسنطيع " and " إغتتم الريح الطيبة" by Attia. It seems that the first Arabic version is too 
literal and can barely convey the ST implied meaning, which is stated above. This translation expresses the general meaning of CSP but does not reflect its specific cultural connotation. Similarly, Attia's second rendition of the ST is too general and quite vague and it neither communicates the ST real intention nor does it indicate its function.

In the same vain, Jabak has rendered the original text into" وقت ", which seems too free and general while the ST is all about enjoying the present moment as much as possible, i.e. "enjoy yourself while you can, before you lose the opportunity or before you become too old" (Spears, 2005, p. 236). The ST can be best transferred into the following cultural functional equivalent:

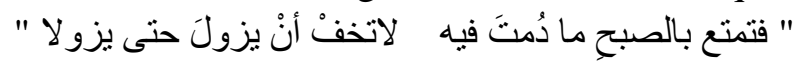

7. "Your looking-glass will tell you what none of your friends will"( "(Attia, 2004, p. 201).

\begin{tabular}{|c|}
\hline $\begin{array}{l}\text { " Your looking-glass will tell you what none of your friends } \\
\text { will ". }\end{array}$ \\
\hline $\begin{array}{l}\text { "No one than yourself can know your own flaws well " } \\
\text { (p. 201). }\end{array}$ \\
\hline $\begin{array}{l}\text { " تخبرك مرآنك بما لايخبرك به أحد من أصدقائك (Attia, 2004, } \\
\text { p. 201). }\end{array}$ \\
\hline
\end{tabular}

In this example, the ST intention is concerned with the fact that man knows his flaws very well regardless of his indifference or denials. Therefore, no one can tell you about your shortcomings better than yourself (your inner mirror).

The ST is rendered too literally into تخبرك مر آتك بما لايخبرك به أحد من "أصدقائك " (lit. your mirror can tell you what your friends cannot) where it appears so unfamiliar and unnatural to the target readers. It is worth noting that the image of mirror is often used in similar contexts in Arabic 
with the addition of the word " داخة "(lit. inner) or the expression" نفسك " ( lit. mirror of yourself). This translation conveys neither the intended meaning nor its embedded cultural connotations adequately. Such literal translation strategy seems to distort the original (Nida, 1983) since the ST message is lost in the TT, i.e. both the ST real intention and the cultural element are not well-communicated.

Conversely, the ST can be well translated into a highly functional

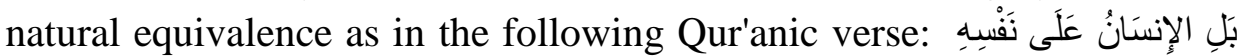

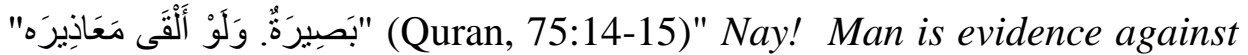
himself. Though he puts forth his excuses" (Shaker, 2008). This translation expresses approximate similar ST meaning and function and it is quite reader-friendly.

8. "Curiosity killed the cat" (Othman, 2013, p.43).

\begin{tabular}{|l|l|}
\hline & " " Curiosity killed the cat". \\
\hline & " too much worry/sorrow leads to death " (p. 43). \\
\hline "الفضول قتل القطة" (Othman, 2013, p. 43).
\end{tabular}

In example (8) the ST proverbial expression 'curiosity killed the cat' is basically to advise someone to avoid too much worry. It is concerned with the fact that being too curious and worried can be dangerous. Cats are curious animals that like to investigate, but their curiosity can take them to places where they might get hurt. The earlier form was still in use in 1898, when it was defined as follows:

"Care killed the Cat. It is said that a cat has nine lives, but care would wear them all out" (Brewer's Dictionary of Phrase and Fable).

The CSP in example (8) is translated into a too literal counterpart, namely" الفضول قتل القطة", which illustrates that utilizing word-for-word translation strategy in dealing with proverbs is problematic. Specifically, the ST real intention and function have not been maintained in the TT. 
Obviously, proverbs in general and CSPs, in particular, cannot be taken literally since literal and/or formal rendition results in distorting the ST in terms of meaning and style (Nida, 1983; see Baker, 2011).

The cultural gap found in the ST, in the example above, can be bridged adequately by resorting to both Baker's ( 2011) CSS and Vanuti's (2008) DS. More specific, 'cat' can be substituted by 'man' and the whole ST is domesticated in the TT as in the following popular functional equivalence:

(Othman, 2013, p.43). Adopting such translation strategies provides the nearest natural equivalence of the TT since "applying a free translation process would be the perfect way to render such cultural signs. Free translation provides the nearest equivalent Arabic expression in order to achieve an effective translation for the TL recipients" (Othman, 2013, p.43).

9. "As you make your bed, so you must lie in it " (Ridout \& Witting, 1983, p.26).

\begin{tabular}{|c|}
\hline "As you make your bed, so you must lie in it ". \\
\hline $\begin{array}{l}\text { "All of us are responsible for the consequences of our actions" } \\
\text { (p.26). }\end{array}$ \\
\hline 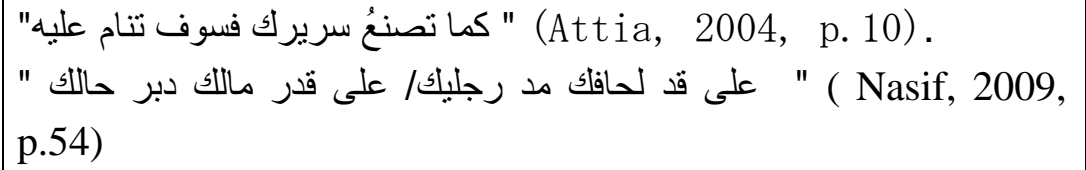 \\
\hline
\end{tabular}

In example (9), the CSP literally means that should "you make your bed badly, you will probably have(an ) uncomfortable night, for 
which you will have only yourself to blame"( Ridout \& Witting, 1983, p.26). Figuratively, the ST intention is that one will surely encounter the consequences of one's actions sooner or later.

Bearing this in mind, the ST is translated by Attia into too literal counterpart, namely" كما تصنغ سريرك فسوف تنام عليه ", which seems inadequate because it concentrates on the ST outward meaning. The translator appears inattentive to the ST embedded meaning, as stated above, and he thus resorts to literal translation strategy, which leads to misunderstanding of the ST real intention and function.

On a similar scale, Nasif has come up with two TT versions, namely" على قدر مالك دبر حالك " and " على قد لحافك مد رجليك, respectively. The first Arabic equivalence " على قد لحافك مد رجليك جلى " is a colloquial proverbial expression which has nothing to do with the ST intended meaning since the CSP, cited above, is concerned with how one is deemed to encounter the outcomes of one's actions. The second Arabic version" على قدر ماللك دبر حالك is about how one can run his life affairs according to the money one has. This latter meaning is also far from the meaning of the original text, which is quite the same as "as you sow, so shall you reap"(Ridout \& Witting, 1983, p.26).

It is worth noting that Arabic is rich with many cultural functional

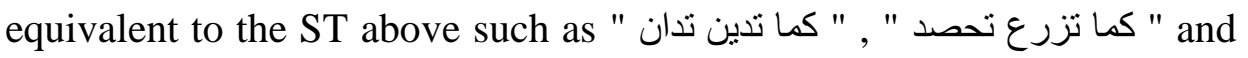
" من حفر حفرةً لأخية وقع فيها ". In addition, the ST can be best communicated via citing the following Qur'anic verses:

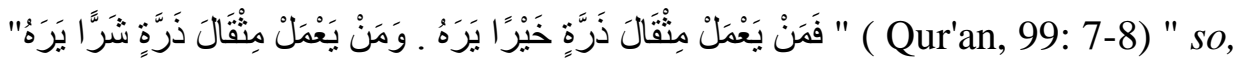
he who has done an atom's weight of good shall see it. And He who has

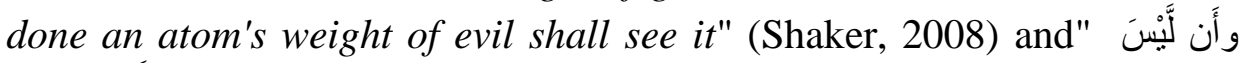

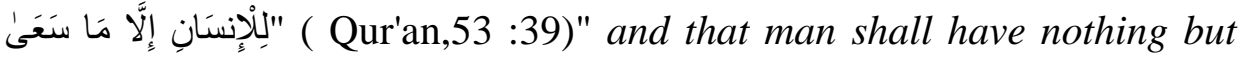
what he strives for" ( Shaker, 2008). Also, the CSP in example (9) can be

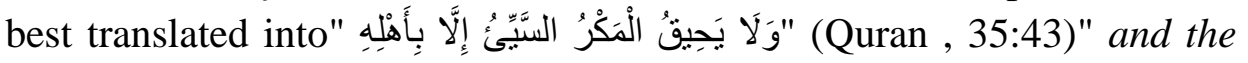
evil plans shall not beset any save the authors of it"( Shakir, 2008).

10. " A soft answer turnth away wrath"( "(Ridout \&Witting, 1983, p.148).

" a soft answer turnth away wrath/ fair words slake wrath". 


\begin{tabular}{|c|c|}
\hline & $\begin{array}{l}\text { "It is better not to lose temper with anyone who angers } \\
\text { you. Your gentle and polite answer will most likely make } \\
\text { him feel sorry for what s/he has done" (p. 148). }\end{array}$ \\
\hline & 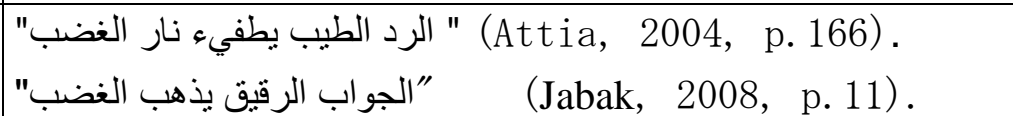 \\
\hline
\end{tabular}

In example (10), the meaning of the CSP is that it is better for us not to lose temper and shout at anyone who angers us. Instead, it is better to face his/her rage with a gentle and polite answer, which will most likely make him feel sorry for what he has done( Ridout \& Witting, 1983, p. 148). The said CSP is originated in the Bible, in Proverbs 15:1: "A soft answer turneth away wrath: but grievous words stir up anger", meaning that responding to someone in a calm, humble manner will help assuage their anger or avoid any further trouble "(Farlex Online-Dictionary, 2015).

The ST is rendered by Attia and Jabak into

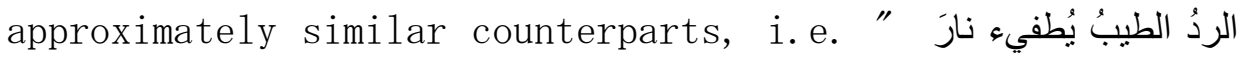
" and" الجوابُ الرقيقُ يُذهبُ الغضبَ " , which though communicated the ST meaning but it is too literal and do not express the ST function adequately. Specifically, expressions like " الجواب الرقيق "and " الرد الطيب " are not commonly used in the TT since there are many we11established Arabic alternative equivalents. The ST can be well communicated in the TT through using an Arabic functional and natural religious equivalents such as " الكلمة "الطيبة صدقة" and" إنزع الثر من صدر غيرك بنزعه من صدرك ". Besides, the ST can be best translated into the Qur' anic highly illustrative counterpart as in the verse:

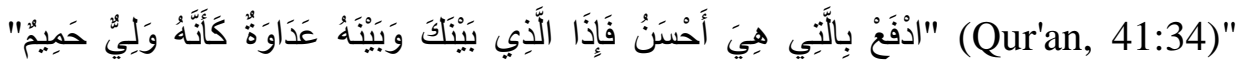
repel(evil) with what is best, when lol he between whom and you was enmity be as if he were a warm friend"(Shaker, 2008). In this Qur'anic counterpart, the ST message seems to be fully communicated for the 
meaning and the related religious cultural connotations of the original are all embedded in the cited verse.

\section{Conclusions}

Based on the pragmatic analysis conducted so far, it is concluded that translating proverbs in general and CSPs, in particular, is not an easy task since they are not meant to be translated literally by simply providing their word-for-word equivalents. Specifically, CSPs express meanings that extend beyond their denotative meaning, i.e. the meanings CSPs convey are largely embedded in socio-cultural and ideological structure. Accordingly, translators of CSPs are required to not only have adequate knowledge and experience of the two languages but also of the two cultures.

Accordingly, the examined translations have revealed that the selected translators, namely, Attia, Nasif, and Jabak appear to have often hardly captured the ST intended meaning and they, therefore; have produced Arabic versions of the ST that look inaccurate and even imply the opposite of the ST intention. Specifically, instead of focusing on context-based equivalents of the ST, the translators often resort to its most circulated versions, which sometimes prove to be inadequate and misleading. Besides, the selected translators often appear neither to have consulted the ST socio-cultural and situational background to determine the ST intention nor have they checked the TL relevant sources to provide approximate counterpart to the TT. However, the selected translators have occasionally produced the closest TT counterpart of the ST in terms of meaning and function very adequately. This indicates that translatability of a given text is undoubtedly translator-dependent. In this respect, Attia has often shown a high level of proficiency in translating CSPs, as compared to Nasif and Jabak who appear to indicate (a)low level of adequacy in the same respect.

As for as translation strategies are concerned, the selected translators ever and again tend to employ literal translation strategy, which leads to distorting the ST spirit and to misunderstanding of its real intention and function. By so doing, they deprive the TT recipients of the 
enjoyment of CSPs sublime style which the ST readers entertain. Most importantly, the selected translators' utilization of literal translation strategy seems to be due to their lack of the cultural and historical background of the CSPs under analysis. In this study, the translation strategies proposed, namely FS, DS and CSS seem to be the best strategies when dealing with highly cultural items, such as CSPs. In In view of the data analysis, those translators can easily express both the ST intention and function in the TT had they skillfully employed the translation strategies proposed so far. Moreover, the data analysis has shown that Arabic is rich with the cultural, functional and natural closest equivalents of the English CSPs.

\section{References:}

1. Abbasi, G. et al. (2012). Language, translation, and culture". 2012 International Conference on Language, Media and Culture IPEDR, 33, 83-87.

2. Abo AL-Timen, F. A.(2015). An Analysis of Translation Methods for English Proverbs: Literal, Literary or Substitution. European Academic Research, Vol. II, Issue 11/ February 2015,pp.14016- 14026.

3. Al-Azzam, Bakri H.S. (2017).Culture as a Problem in the Translation of Jordanian Proverbs into English. International Journal of Applied Linguistics \& English Literature, 7,1,pp.56- 63.

4. Al-Dammad, Abdulaziz (2004). Domestication vs. Foreignization in Englsih Arabic Translation. Retrieved from Mahatat,20/8/2020, Alarabia.net)

5. Alfaleh, B. A. (2020).Translation Quality Assessment of Proverbs from English into Arabic: The Case Study of One Thousand and One English Proverbs Translated into Arabic. Arab World English Journal (AWEJ), Pp. 1- 56. 
6. Al-Saidi, A. (2014). Misinterpretation of culture-loaded English proverbs into Arabic: A domestication approach. Retrived from academia.edu.

7. Al-Saidi, A. H.(2016). The Illusion of Untranslatability: A Theoretical Perspective with Reference to the Translation of CultureBoundEuphemistic Expressions in the Qur'an. IJALEL, 5 , 3, pp.81-90.

8. AlSaidi, A. H.(2016b). Socio-Pragamtic Failure in the English Translations of the Euphemstic Culture-bound Expressions in the Qur'an by Non-Muslim Translators (Unpublished Ph.D thesis): University Putra Malasia.

9. Al-Shammari , J. N. (2015). Examining Nida's Translation Theory in Rendering Arabic Proverbs into English: A Comparative Analysis Study. International Journal of English Language and Linguistics Research , 3, 8, pp.45-57.

10. Arora, Shirley (1995). The Perception of Proverbiality. In Wolfgang Wise Mieder (Ed.),Wise Words Essays on the Proverb. New York \& London: Garland Publishing Inc., pp. 3-29.

11. Assaqaf, T.A. (2019). Techniques for Interpreting English Proverbs into Arabic. International Journal of Language and Literary Studies, 1, 1, pp. 73-80.

12. Attia, M. (2004). Dictionary of common English proverbs. Retrieved from http://www. attiaspace. com/Publications/CommonProv erbs. pdf.

13. Bahumaid, S. (2017). Culture-bound Terms in ArabicEnglish Translation: Difficulties and Implications. Applied Linguistics, vol. 6 , pp. 25-39.

14. Baker, M \& Saldanha, G. (Eds.). (2009). Routledge encyclopedia of translation studies. USA \& Canada: Routledge 
15. Baker, M. (1992/2011). In Other Words: A Coursebook on Translation (2nd ed.). London and New York: Routledge.

16. Benard. M. (2018). Baker's Strategies in Translation: A Lexico-Semantic Analysis of Four Luhya Dialects; Lukabras, Lwisukha, Luwanga and Lukhayo in Informative Text. AJESS,3, pp.71-84.

17. Casagrande, J. (1954). The ends of translation. International Journal of American Linguistics, 20, 335-336.

18. Daghoughi, S., \& Hashemian, M. (2016). Analysis of culture-specific items and translation strategies applied in translating Jalal Al-Ahmad's By the Pen. English language teaching. 9(4), pp.171-185.

19. Dweik,B. and Thalji,M(2016). Strategies for Translalting Proverbs from English into Arabic. Academic Research International, vol.7(2) pp.120-27.

20. Farahani , A. K. and Ghasemi, M. (2012). The Naturalness in Translation of Idioms and Proverbs: The Case of a Persian Translation of Pinocchio. Journal of language and Translation, 3 (1), pp.17-21.

21. Faiq, S. 2004. The Cultural Encounter in Translating from Arabic. In: S. Faiq. (ed.). Cultural Encounters inTranslation from Arabic. Clevedon, Buffalo and Toronto: Multilingual Matters, 1-13.

22. Ghazala, H. (1995). Translation as Problems and Solutions, 4th editon, Syria: Dar El-Kalem El-Arabi.

23. Ghazala, H. (2014). Translation as problems and solutions. (10th ed.). Jeddah: Konooz Elmarefa.

24. Gimblett, K.(1973). "Toward a Theory of Proverb Meaning." Proverbium 22,pp. 821-26.

25. Guerra, A. F.(2012). Translating culture: problems, strategies and practical realities, Art and Subversion, 1, 12. pp.1-27.

26. Herrag, E. (2012). The Ideological Factor in the Translation of Sensitive Issues from the Qur'an into English, Spanish and Catalan. (Unpublished doctoral disseration), Barcelona University. 
27. House, J. (2009). Translation. New York: Oxford Univerity Press.

28. -------_ (2015). Translation quality assessment: Past and present. London\& New York: Routledge

29. Issa, H. (2017). Translating figurative proverbs from two Syrian novels: Muftaraq al-Matar by Yusuf a1-Mạ̣ mūd and Anājīl al-Xarāb by Naufal Nayouf. Arab World English Journal for Translation \& Literary Studies, $1(2)$.

DOI :

http://dx. doi.org/10. 24093/awejt1s/vo11no2. 6

30. Jabak, O.(2008).One Thousnad and One English Proverbs Translated into Arabic. Retrivede from https://www.pinterest.com/pin/822610688172013346.

31. Katan, D. (2004). Translating Cultures: An Introduction for Translators, Interpreters and Mediators. London \& New York: Routledge.

32. Larson, M. L. (1984). Meaning-Based Translation: A Guide to Cross-Language Equivalence. Lanham and New York: University Press of America Inc.

33. Levine, Suzanne J.(1991). The Subversive Scribe. Translating Latin American Fiction. . Minesota: Graywolf Press/ Saint Paul, Print

34. Mieder, W. (2004). Proverbs: A Handbook. USA: Greenwood press.

35. Mieder, W.. (2008). Proverbs speak louder than words": Folk wisdom in art, culture, folklore, history, literature and mass media. New York: Peter Lang.

36. Miller -Naude, C. L. and Nadue, J. A. The Translator as an Agent of Change and

37. Transformation: The Case of Translating Biblical Proverbs (2010). Agent of Change OTE 23/2 (2010), 306-321.

38. Nasīf, Shadi (2009). Qamūs al-Hikam walAmthal alEnjiliziya (trans.Dictionary of English Wise Sayings and proverbs). Damascus: Dar al-Kitab al-Arabi. 
39. Nida, E. A. (1964). Towards a Science of Translating. Leiden, Holland: E.J. Brill.

40. Nida, E.A. and Charles R.Taber. 1969. The Theory and Practice of Translation. Leiden: EJ.Brill.

41. Nida, E.A. 1984. "Approaches to Translating in the Western World". In Foreign Language Teaching and Research. No. 2.

42. Nida, E. A., \& Waard, J. d. (1986). From One Language to Another: Functional Equivalence in Bible Translating. Nashville: Nelson Publishers.

43. Nida, E. A (1993). Language, Culture and Translating. Shanghai: Shanghai Foreign Language Education Press.

44. -------(2001). Language and Culture: Contexts in Translating: John Benjamins Publishing Co

45. Nord, C. (1997). Translating as a Purposeful Activity. Manchester: St. Jerome.

46. Othman, A. O. (2013). An Analysis of the Role of Micro and Macro Levels in Rendering Some Standard Arabic Proverbs into English (unpublished Ph.D. Thesis ), UK:University of Leeds.

47. Samovar, L., Porter, R., \& McDaniel, E. (2009). Communication between cultures. Cengage Learning.

48. Sapir, E. (1949). Culture, Language, and Personality: Selected Essays. California: University of California Press.

49. Searle, J. (1969). Speech Acts: An Essay in the Philosophy of Language. Cambridge: Cambridge University Press.

50. Searle, J. (1979). Expression and Meaning. Cambridge: Cambridge University Press.

51. Shakir, M.H.(2008) Holy Quran(Trans.).Qum: Ansariyan.

52. Shehab, E.a and Daragmeh ,A. (2015) A Context-based Approach to Proverb Translation: The Case of Arabic into English Translation: Translation Review, 90:1, pp. 51-68.

53. Speake, J. (Eds.). (2008). Oxford dictionary of proverbs. Oxford: Oxford University. 
54. Spears, R. A. (2005). McGraw-Hill's dictionary of American idioms.

Retrieved from http://english4success.ru/Upload/books/959.pdf

55. Spencer-Oatey, H. (2008). Culturally Speaking: Culture, Communication and Politeness Theory: University of Michigan: Continuum.

56. Thalji, M.B.(2015).The Translation of Proverbs: Obstacles and Strategies (unpublished MA Thesis) Middle East University: Amman-Jordan.

57. Thomas, J. (1983). Cross-cultural pragmatic failure. Applied Linguistics, 4, 91-112.

58. Venuti, Lawrenc.(1995/2008). The Translator's Invisibility: A History of Translation. London:Routledge.

59. Venuti, L. (1998). The Scandles of Translation. Twards an Ethics of Difference. London/ New York: Routledge.

60. Witting, Ridout (1964/1984). English Proverbs Explained. London: Heinemann.

61. Wu, Jianqing (2008). The Analysis of Cultural Gaps in Translation and Solutions. English Language Teaching, 1, 2, pp.123-127.(1,(2),123-127)

62. Zahrawi, Samar (2018). Maintaining Cultural Identity in Translated Literary Texts: Strategies of Translating Culture-Specific Items in two Arabic plays. AWEJ for Translation \& Literary Studies, 2, 2, Pp. 2-16. ( 2,(2), 2-16)

63. Zhang, Q. (2010). Application of functional equivalence theory in English translation of Chinese idioms. Journal of Language Teaching and Research, 1(6), 880-888.

\section{About the author:}

Abdali Hammood al-Saidi is currently a member of the teaching staff at English Department / College of Arts/ Thiqar University. He got his MA in translation and linguistics from College of Arts/ Baghdad University (2006) and his Ph.D. in pragmatics of translation from the Faculty of 
Modern Languages and Communication, University Putra Malaysia (UPM), Serdang(2016). His research interests and publications are in the areas of translation and culture.

Email:brunosaidi8@yahoo.com

\section{تحليلّ تداولي لترجمة الأمثال الإنجليزية ذات الخصائص الثقافية الى التى اللغة العربية}

$$
\text { أ.م .د. عبدة علي حمود شيحان السعيدي }
$$

خلاصة البحث

تعد ترجمة الأمثال الإنجليزية ذات الخصائص الثقافية مهمة في غاية الصعوبة كونها

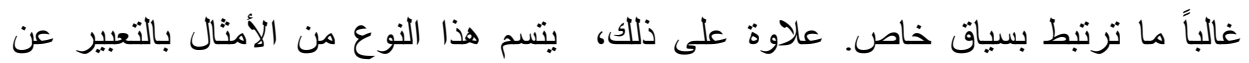

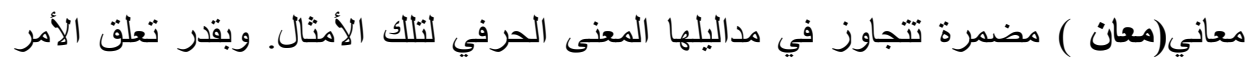
باللغتين اللإنجليزية والعربية، يواجه المنرجمون في كثير من الأحيان مشاكل(مشكلات) متعددة

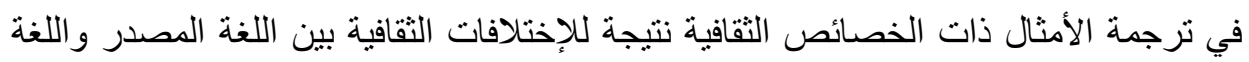
الهدف مضافاً لما يبدو من عدم وجود المكافيء لبعض تلألك الأمثال.

وفي ضوء ذللك، يتتاول هذا البحث ترجمة الأمثال ذات الخصائص الثقافية في ثلاثة قواميس ثنائية اللغة( أنجليزي- عربي) هي كالتالي: "قاموس الأمثال الأنجليزية مترجمة

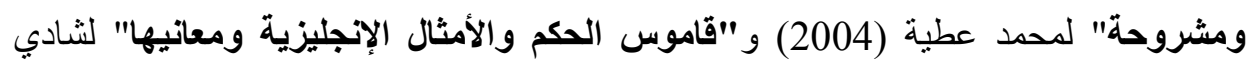
ناصيف و "قاموس ألف مثل ومثل انجليزي مترجم الى اللغة العربية" لعمر عثمان جبق.

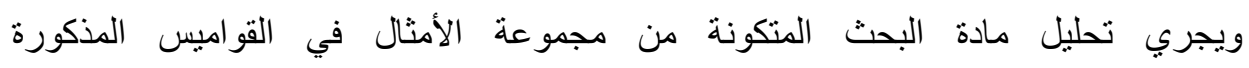

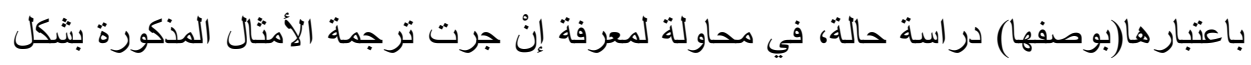
حسن وفيما إذا عكست استر اتيجيات الترجمة، التي جرى نوظبفها، المعنى الحقيقي والايحاءات الثقافية التي تتضمنها تلك الأمثال. ومن بين مجموع مادة البحث التي تبلغ 50 مثنلا، جرى إختيار

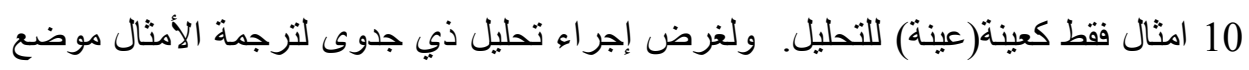
البحث، نم تكيف( كيف ) نموذج نظري انتقائي يتكون من ثناثة استراتيجيات للترجمة هي 
الاستبدال الثقافي لمنى بيكر (2011) و التوطين لفينوتي ( 2008 ) و المكافيء الوظيفي لنايدا( 1964/1975). ويعد هذا النموذج الإنتقائي الإطار النظري الأساس لهذه الدراسة.

وتبين نتائج البحث إنَّ عينة التراجم المختارة نظهر الى حد كبير ما يبدو كمستوى

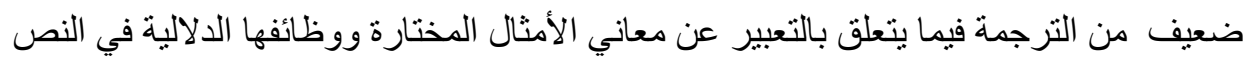
الهدف. بمعنى أكثر دقة، لقد جاء المترجمون الذين تم أختيار هم بترجمات غير كفوئة للألالات الثقافية للأمثال موضوع الدراسة في النص الهدف. مضافا لذلك، تُبين هذه الدراسة أنَّ بإمكان

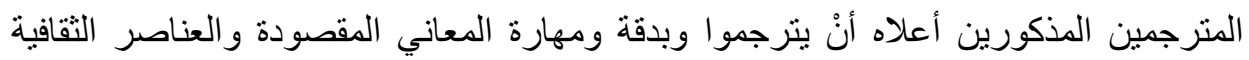

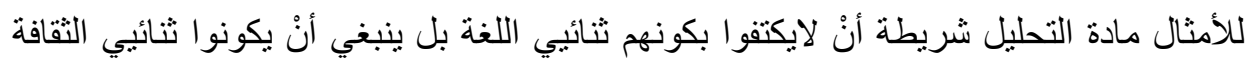

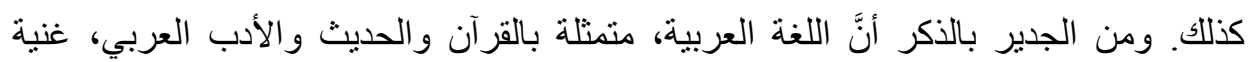

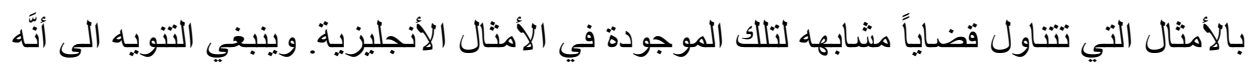

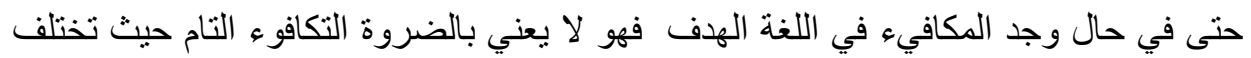
طريقة التعبير عن معنى الأمثال واستخدامها بين اللغات.

الكلمات المفتاحية: الأمثال ذات الخصائص الثقافية، الثقافة، الترجمة، استر اتيجية الترجمة 